УДК 82I.I6I.I

ББК $83.3(2 \mathrm{Poc}=\mathrm{Pyc}) 52$

\section{БОГУЧАРОВСКИЙ «БУНТ» В «ВОЙНЕ И МИРЕ» Л.Н. ТОЛСТОГО: ИСТОЧНИКИ, ФИЛОСОФИЯ, ПОЭТИКА}

\author{
(C) 2020 г. А.В. Гулин \\ Институт мировой литературы \\ им. А.М. Горького Российской академии наук, \\ Москва, Россия \\ Дата поступления статьи: І2 января 2020 г. \\ Дата публикации: 25 марта 2020 г.
}

DOI: IO.22455/2500-4247-2020-5-I-I62-I77

Исследование выполнено при финансовой поддержке РФФИ в рамках научного проекта № 20-оI2-оОIо2

Аннотация: В статье предпринята попытка комплексного анализа сцен богучаровского «бунта» - единственного в «Войне и мире» эпизода, посвященного теме народных волнений. Рассмотрение использованных Л.Н. Толстым исторических источников позволяет сделать вывод о глубокой укорененности художественной картины несостоявшегося мятежа в реалиях І8І2 г. Выявляется соотношение в национальном сознании эпохи фигур Емельяна Пугачева и Наполеона Бонапарта как разных воплощений единой жизненной модели, провозгласившей волю грешного человека единственной движущей силой бытия. В то же время выявлено своеобразие идейной позиции Толстого, которая опиралась на принцип «Нет в мире виноватых». Сцены богучаровского «бунта» рассмотрены с точки зрения сквозного в романе конфликта естественной жизни и цивилизации. Поэтика эпизода оказывается при этом производной от религиозно-философских воззрений писателя и представляет собой поэтику непринужденного чувства и действия. Сцены богучаровского «бунта» получают в романе наряду с ярко реалистическим отображением русской истории характер цивилизованного помрачения естественной жизни. Художественный реализм и религиозно-философский утопизм выступают у Толстого в парадоксальном и продуктивном взаимодействии.

ключевые слова: Толстой, Пушкин, Пугачев, Наполеон, цивилизация, роман, история, народ, Николай Ростов.

Информация об авторе: Александр Вадимович Гулин - доктор филологических наук, ведущий научный сотрудник, Институт мировой литературы им. А.М. Горького Российской академии наук, ул. Поварская, д. 25 а, г2Іо69 г. Москва, Россия.

E-mail: gulinimli@yandex.ru

Для цитирования: Гулин А.В. Богучаровский «бунт» в «Войне и мире» Л.Н. Толстого: источники, философия, поэтика // Studia Litterarum. 2020. Т. 5, № I. С. I62-I77. DOI: I0.22455/2500-4247-2020-5-I-I62-I77 


\title{
THE "REBELLION" IN BOGUCHAROVO IN LEO TOLSTOY'S WAR AND PEACE: SOURCES, PHILOSOPHY, POETICS
}

This is an open access article

distributed under the Creative Commons Attribution 4.0 International (CC BY 4.0)

\author{
(C) 2020. A.V. Gulin \\ A.M. Gorky Institute of World Literature \\ of the Russian Academy of Sciences, \\ Moscow, Russia \\ Received: January $\mathbf{1 2}, 2020$ \\ Date of publication: March 25, 2020
}

Acknowledgements: This research was supported by Russian Foundation for Basic Research, project no 20-OI2-OOIO2

Abstract: The article attempts to comprehensively analyze the scenes of "the revolt in Bogucharovo," the only episode in War and Peace devoted to the theme of civil unrest. The study of the historical sources used by Tolstoy allows us to conclude that the literary representation of a failed rebellion was deeply rooted in the realities of I8I2. The article reveals a correlation in the national consciousness of the epoch between the figures of Emelyan Pugachev and Napoleon Bonaparte as different embodiments of a single life model, which proclaimed the will of a sinful man as the only driving force of existence. The article also brings to light the originality of Tolstoy's ideological position, which was based on the principle "There are no guilty people in the world." The author examines the scenes of "the revolt in Bogucharovo" from the standpoint of the conflict of natural life and civilization, which is present throughout the novel. The poetics of the episode, that is the poetics of spontaneous emotion and action, is derived from the religious and philosophical views of the writer. The scenes of "the revolt in Bogucharovo" in the novel realistically present episodes of Russian history and artistically "darken" the natural course of life. Artistic realism and religiousphilosophical utopianism in Tolstoy's novel interact in a paradoxical yet productive manner.

Keywords: Tolstoy, Pushkin, Pugachev, Napoleon, civilization, novel, history, people, Nikolai Rostov.

Information about the author: Alexander V. Gulin, DSc in Philology, Leading Research Fellow, A.M. Gorky Institute of World Literature of Russian Academy of Sciences, Povarskaya 25 a, I21069 Moscow, Russia.

E-mail: gulinimli@yandex.ru

For citation: Gulin A.V. The "Rebellion" in Bogucharovo in Leo Tolstoy's War And Peace: Sources, Philosophy, Poetics. Studia Litterarum, 2020, vol. 5, no I, pp. I62-I77. (In Russ.) DOI: I0.22455/2500-4247-2020-5-I-I62-I77 
$\mathbf{I}$

«Война и мир» - эпическая книга о народном единстве, о торжествующей в I8I2 г. «сущности характера русского народа и войска». Внутренние распри, братоубийственная война никак не должны были оказаться в поле зрения Толстого - исторически или духовно. Сословные, идеологические противоречия русского мира (если не принимать в расчет эпилог «Войны и мира») действительно выглядят в романе примиренными домашней, семейной правдой национального жизненного уклада. Лучшее тому свидетельство - братское единство господ Ростовых и ловчего Данилы в потрясающих «охотничьих» сценах произведения.

Тем не менее вполне очевидно, что роман Толстого, в силу своей эпической всеохватности, должен был так или иначе отобразить все сколько-нибудь значительные стороны национальной действительности в эпоху войны с Наполеоном. И память о событиях гражданской войны XVIII в., о Пугачевщине как устремленном в будущее разрушительном духовном явлении, хотя и с большим своеобразием, тоже напомнила о себе в романе. Речь идет прежде всего о картинах так называемого «богучаровского бунта», которые занимают несколько глав во второй части III тома «Войны и мира».

Собственно, Толстой показал бунт не вполне состоявшийся, едва наметившийся. Суть его, как известно, свелась в романе к тому, что мужики села Богучарово перед лицом близкой наполеоновской оккупации не только отказались покинуть свои дома и уехать вместе с княжной Марьей Болконской вглубь страны, но и насильственно удерживали в имении саму только что осиротевшую княжну. Ее спасителем и усмирителем 
бунта неожиданно для себя оказался Николай Ростов, случайно заехавший в Богучарово в поисках фуража для своей воинской части.

Как всегда в «Войне и мире», Толстой опирался в своем повествовании на подлинные факты и происшествия. В случае с богучаровским «бунтом» источники эпизода выглядят не вполне определенными, тем не менее можно не сомневаться, что и здесь писателем руководил вовсе не беспочвенный полет фантазии, что перед нами один из ярких примеров толстовской художественной типизации.

Прежде всего, Толстой, очевидно, имел в виду события, происходившие летом І8І2 г. с его дедом Н.С. Волконским и матерью М.Н. Волконской. На это обстоятельство в свое время обратил внимание А.Г. Тартаковский, который издал в 1990 г. дневник Д.М. Волконского - двоюродного дяди писателя. Автор дневника, покинув Москву вместе с русской армией, направился в Ясную Поляну к брату своего отца и деду Толстого. «Заехал на дороге в кабак узнать, тут ли дядя, - отметил он, - нашел пьяного ундер-офицера, который доказал мне грубостию, сколь народ готов уже к волнению, полагая, что все уходят от неприятеля. Приехав в деревню, узнал я, что дядя и с дочерью поехали тому два дни в Тамбовскую деревню к княгине Голицыной, начавшиеся беспорядки и волнения в народе его понудили» [3, с. I45-I46]. За этим глухим свидетельством, по всей вероятности, скрывались происшествия, гораздо лучше известные Толстому по семейным преданиям.

Факты народного неповиновения в I8I2 г., несмотря на деликатность этой темы, отмечали также и некоторые другие современники событий. Природа таких волнений была, как правило, неоднозначной. Иногда за поступками крестьян можно было предположить смутное желание с приходом Наполеона избавиться от крепостной зависимости. Подобные мотивы угадываются, например, в рассказе смоленского помещика А.А. Кононова о крестьянской семье, которая выказала очевидную дерзость в момент приближения французских войск и отъезда своих господ вглубь России: «У нас был молодой парень, Петр, он ездил форейтором. Когда все уже было готово к выезду, 6-го августа, описанному мною, пришли сказать, что Платон, отец его, и его жена, оставляют сына при себе и не позволяют брать его. Батюшка велел их позвать; они пришли и с наглым видом объявили, что не отпустят сына, прибавляя: “Прошла ваша власть, едете сами, Бог ведает куда, Бог ведает, что с вами будет, не даем сына!” В то время подобная выходка одна могла повести к 
бунту. Отец мой сказал: “Пусть так, пусть сын ваш остается; но знайте, что если я возвращусь, он в первый набор будет рекрут". Они отвечали с дерзостию: “Не стращайте, не стращайте! Не вернетесь, батюшка!” [6, с. 23I]. По словам малолетнего в ту пору мемуариста, крестьянский сын после их возвращения действительно был отдан в солдаты. Записки Кононова увидели свет на страницах «Чтений в Обществе истории и древностей российских», выпусками которых Толстой интересовался в годы создания «Войны и мира».

Наряду с огромным энтузиазмом, который вызвал в народе объявленный набор ополченцев, это событие также не проходило без тяжелых сцен, а возможно, и отдельных признаков народного недовольства. «Мы отложили нашу поездку в деревню, - сообщала М.А. Волкова своему корреспонденту В.И. Ланской (Толстому эти письма были известны в подлиннике), - узнав, что там происходит набор ратников. Тяжелое время в деревнях даже на гоо человек одного берут в солдаты и в ту пору, когда кончены полевые работы. Представь же, что должно быть теперь, когда такое множество несчастных отрывается от сохи. Мужики не ропщут; напротив, говорят, что они все охотно пойдут на врагов, и что во времена такой опасности всех следовало бы брать в солдаты. Но бабы в отчаянии, страшно стонут и вопят, так что многие помещики уехали из деревень, чтобы не быть свидетелями сцен, раздирающих душу» [4, с. 588].

Главная же причина, возбуждавшая ропот среди крестьян и даже отмеченные современниками вспышки народного гнева, состояла в недостаточном, по их мнению, патриотизме и приверженности господ французским обычаям и языку. Все европейское вызывало в деревнях подозрительность и неприязнь, пробуждая в то же время давние сословные противоречия.

Трудности переживали многие из тех, кто летом І8І2 г. решил покинуть Москву. Эти люди, как передавал сенатор А.Д. Бестужев-Рюмин, «находили в пути своем большие неприятности или, лучше сказать, были в величайшей опасности от подмосковных крестьян, чрез селения которых должны были ехать». Мемуарист говорил о крестьянах: «Они называли удалявшихся трусами, изменниками и бесстрашно кричали тем, которые мимо селений ехали: “Куда, бояре, бежите вы с холопами своими? Али невзгодье и на вас пришло? И Москва в опасности вам не мила уже? И которые из удалявшихся по необходимости и должны были останавливаться в селениях, для отдохновения и корму лошадей, то таковые вынуждаемы были хозяевами дворов, 
у которых останавливались, платить себе за овес и сено втридорога, и сверх того просто за постой <..>, и беспрекословно должны были повиноваться сему закону, если не хотели сделаться жертвою негодования противу своего побегу освирепевшего народа. Многие из удалявшихся из Москвы на своих собственных лошадях возвращались опять в Москву пешками, лишившись дорогою и лошадей своих и с экипажем и имущества» [9, т. 2, с. 79].

Сцены богучаровского «бунта» в «Войне и мире» отражали действительную сложность и неоднозначность восприятия событий в крестьянской среде, возникающие порой на фоне общей готовности сопротивляться врагу неожиданные духовные «помрачения». И картины несостоявшегося бунта определенно проецировались тут на неистребимую в веках память о грозных потрясениях ушедшего столетия. Это была только тень Пугачевщины, не более того, но ее присутствие выглядело в русском мире времен первой Отечественной войны совершенно реальным. Не менее очевидным оказалось оно и в романе Толстого.

Рассказ о «бунте» в Богучарове предварялся на страницах «Войны и мира» исключительно яркой характеристикой проживающих здесь («диких», по определению старого князя Болконского) мужиков: «Между ними всегда ходили какие-нибудь неясные толки, то о перечислении их всех в казаки, то о новой вере, в которую их обратят, то о царских листах каких-то, то о присяге Павлу Петровичу в I797 году (про которую говорили, что тогда еще воля выходила, да господа отняли), то об имеющем через семь лет воцариться Петре Федоровиче, при котором все будет вольно и так будет просто, что ничего не будет. Слухи о войне и Бонапарте и его нашествии соединились для них с такими же неясными представлениями об антихристе, конце света и чистой воле» [9, т. ІІ, с. І42]. Оставляя до времени вопрос о совершенно очевидной иронической тональности писателя, стоит обратиться к тем действительным фактам, которые получили суеверное преломление в сознании богучаровских крестьян.

Прежде всего, здесь обращает на себя внимание упоминание императора Павла Петровича. Его недолгое пребывание у власти (I796-I8ог) действительно было отмечено шагами, направленными на облегчение участи крепостных и некоторое урезание власти помещиков, почти совершенно безграничной в минувшую Екатерининскую эпоху. Впервые со времен царицы Елизаветы Петровны крестьяне по его требованию присягали 
в I797 г. новому государю наряду с прочими сословиями. Тогда же Павел Петрович отменил объявленный незадолго до этого чрезвычайно тягостный рекрутский набор, заменил хлебную подать менее обременительной денежной. Было запрещено продавать крестьян без земли, использовать их на барщине больше трех дней в неделю. Они получили право жаловаться на своих владельцев. С точки зрения крепостных, эти меры служили подтверждением давних, со времен Пугачева имевших место толков о «добром наследнике». «Едва только император Павел вступил на престол, - рассказывал историк той эпохи Е.П. Трифильев, - как среди крепостных стали распространяться слухи о перемене их положения, породившие случаи сначала незначительных волнений; но когда ряд указов, следовавших один за другим, показал, что новый государь действительно озабочен положением крестьян и серьезно стремится к его облегчению, тогда крестьяне увидели в новом царствовании <...> ту зарю свободы, которая, казалось, погасла для них навсегда. Крестьяне не хотели верить, что нет указа о свободе, они были убеждены, что этот указ издан новым государем, да его скрывают помещики и власти, ими подкупленные» [Іо, с. 2о].

Еще более многозначительным выглядело в романе упоминание «имеющего через семь лет воцариться Петра Федоровича». Темные обстоятельства, при которых в I762 г. окончил свои дни не успевший даже короноваться император Петр III, дали повод к появлению нескольких самозванцев. Наибольшую известность среди них, конечно, получил Емельян Иванович Пугачев. Он явно эксплуатировал популярные в народе ожидания «мужицкого царя» и слухи о чудесном спасении свергнутого «злой женой» народного государя. Толки богучаровских крестьян из романа по-своему отразили общие для крестьянского мира второй половины XVIII в. смутные настроения, как правило, окрашенные понятиями о конце света и мужицком рае.

Объясняя «дикий» характер богучаровских крестьян, Толстой говорил о «таинственных струях народной русской жизни, причины и значение которых бывают необъяснимы для современников». Далее в романе сказано: «Подводные струи не переставали течь в этом народе и собирались для какой-то новой силы, имеющей проявиться так же странно, неожиданно и вместе с тем просто, естественно и сильно. Теперь, в І8І2-м году, для человека, близко жившего с народом, заметно было, что эти подводные струи производили сильную работу и были близки к проявлению» [9, т. II, с. I43]. 
Замечательно, что в этом рассуждении Толстого ничего не говорится о направлении, которое примут таинственные народные силы: обратятся они в итоге против Наполеоновского нашествия или же взорвут Россию изнутри? Рассматривая события словно бы непосредственно в момент их совершения (важнейший поэтический принцип «Войны и мира»), писатель улавливает здесь некую таинственную альтернативу, независимый от любых логических построений выбор народом своего исторического пути.

\section{2}

В свое время Н.Н. Страхов, размышляя о художественных особенностях «Войны и мира», находил глубинную поэтическую преемственность между романом Л.Н. Толстого и «Капитанской дочкой» А.С. Пушкина. С точки зрения современных представлений о Толстом и его шедевре это мнение выглядит далеко не бесспорным. Зато богучаровские главы романа-эпопеи, безусловно, являются точкой идейного и тематического соприкосновения двух великих произведений русской литературы. Разумеется, это сближение непреднамеренное, укорененное в единстве национальной исторической проблематики.

Особенно заметна сюжетная перекличка романов Толстого и Пушкина в показе тех настроений, которые вызывает у жителей Белогорской крепости и у богучаровских крестьян приближение в одном случае Пугачева, в другом - Наполеона.

Пушкинский герой Петр Гринев рассказывал о постепенно нарастающих среди казаков мятежных настроениях, о каких-то таинственных контактах между казаками и самозванцем, о его обещаниях казачьему миру. Примерно так же накалялась обстановка и в «Войне и мире», где «крестьяне, как слышно было, имели сношения с французами, получали какието бумаги, ходившие между ними», где упоминался некий мужик, который привез от французов «сто рублей ассигнациями (он не знал, что они были фальшивые), выданные ему вперед за сено» [9, т. II, с. I44].

По прочтении того и другого фрагмента трудно избавиться от впечатления, что, помимо вещей самых очевидных, здесь идет речь о действии на человеческую душу и народный мир какой-то обольстительной, помрачающей чувства и разум смертоносной силы, причем силы одной и той же.

Подлинные истоки Пугачевщины (и это хорошо различимо в «Капитанской дочке») таинственны, скрыты в неразгаданных порой суе- 
верных глубинах народной жизни, берущих свое начало в самом первом грехопадении. Богучаровский бунт на страницах романа Толстого, безусловно, явление того же порядка, хотя и вдохновленное теперь уже нашествием передовых европейцев во главе с их «просвещенным» кумиром.

Признавая в Бонапарте самое яркое воплощение, своеобразный «эталон» начал бунтарства и революционности, люди І8г2 г. вполне определенно видели в нем самозванца и «всемирного поджигателя». Позднейшие историки будут спорить, насколько реальными выглядели в период Отечественной войны опасения русской смуты, рассуждать о намерениях и планах на этот счет самого Наполеона. Задним числом тревога людей той поры чаще всего будет казаться необоснованной. Между тем для современников Наполеон и смута выступали как понятия равнозначные. Вот почему, например, один из публицистов эпохи, говоря о Наполеоне, совершенно естественно прибегал к выразительным, говорящим аналогиям: «Правда, что и он в свою очередь много займет места в истории и надолго сохранится в памяти потомства. Но что такое будет память сия как не печать вечного проклятия? - И Картуш разве также не поставлен в истории? - И Пугачев разве также не памятен?» [г, с. 7]. Сравнение Наполеона с Пугачевым для русских современников грозных событий не представляло собой никакого парадокса: поставить нелигитимного французского императора (плебисцит I804 г., одобривший коронацию последнего, воспринимался всего лишь как очередной кощунственный фарс) в один ряд с лжеимператором Петром Третьим было для них совершенно естественно.

Пугачевщина, память о которой далеко еще не стала преданием столетий, означала, с точки зрения современников I8I2 г., не только зловещее историческое событие, но духовный принцип, жизненную модель, провозгласившую самозванство, собственную волю грешного человека главными и определяющими силами бытия. Народный бунт, будь то во Франции эпохи революции, или в России I773-I775 гг., выглядел, с их точки зрения, дорогой к полному торжеству «подлого» честолюбия, вседозволенности и - в итоге - к попранию человеком его божественной природы. В этом смысле Наполеоновская империя как венец революционного самовластья представлялась глубоко родственной царским притязаниям безграмотного донского казака.

Схожими были и плоды что европейского, что русского бунта, в том и другом случае таинственными путями устремленного к покорению 
Москвы. Размышляя после оставления французами древней русской столицы о наполеоновском приказе взорвать напоследок московский Кремль и кремлевские соборы, адмирал А.С. Шишков говорил: «Кто после сего усумнится, чтоб он, если бы то в возможности его состояло, не подорвал всю Россию и, может быть, всю землю, не исключая и самой Франции?» [II, c. II]. Пугачевщина и бонапартизм одинаково, по мнению людей того времени, покушались на основания русской и мировой гармонии, одинаково готовили «переворот» всего света и утверждение в нем безбожной власти.

\section{3}

В отличие от некоторых современников Наполеоновской эпохи и даже от своих современников (среди последних были святитель Феофан Затворник и святитель Игнатий Брянчанинов) Толстой не считал Наполеона предтечей Антихриста. Впрочем, отдельные описания романа в силу своей исключительной художественной полноты и многомерности (как это происходит, например, в почти невероятной сцене, где показан Наполеон перед Москвой на Поклонной горе) независимо от воззрений художника заключали в себе возможность в том числе и такой трактовки образа (см.: [5]). Под этим углом зрения полученные богучаровскими крестьянами «подметные письма», подаренная случайному мужику в знак обещания будущих «щедрот» фальшивая ассигнация (совершенно достоверные подробности из истории г8I2 г.) (см.: [7]) тоже могут интерпретироваться в том числе как некий прообраз будущих искушений всемирного беззаконника. Тем не менее в контексте толстовской философии богучаровский «бунт», конечно, представлял собой нечто совсем иное, являлся, скорее, печальным «сбоем», который дала вечно прекрасная, эмоционально отзывчивая русская действительность.

У истоков замысла «Войны и мира» находилась мечта ее создателя о непринужденном чувствительном единстве всех живущих на свете. Великий поэт земного счастья, Толстой создавал книгу о естественной жизни, которая таит в себе разрешение всех противоречий, заключает в своем течении абсолютную меру хорошего и дурного, дарит человеку вечное, несомненное благо. Название в духе Н.А. Островского «Все хорошо, что хорошо кончается», которое на первых порах Толстой собирался дать своему роману, как нельзя лучше выражало «несущую» идею произведения. «Война и мир» в первую очередь утверждала и прославляла толстовскую мечту о божествен- 
ной, словно никогда не знавшей грехопадения, чувствительной сущности всего, что живет и дышит. «Идеал есть гармония, - записал Толстой в дневнике в год начала работы над романом. - Одно искусство чувствует это. И только то настоящее, которое берет себе девизом: нет в мире виноватых. Кто счастлив, тот прав!» [9, т. 48, с. 53].

Естественная жизнь, чувствительная нравственность не нуждались, по мысли Толстого, ни в каком цивилизованном оформлении. «Жизнь между тем, - говорил он о русском мире в канун войны г8І2 г., - настоящая жизнь людей с своими существенными интересами здоровья, болезни, труда, отдыха, с своими интересами мысли, науки, поэзии, музыки, любви, дружбы, ненависти, страстей шла, как и всегда, независимо и вне политической близости или вражды с Наполеоном Бонапарте, и вне всех возможных преобразований» [9, т. Іо, с. I5I].

Природа больших и малых конфликтов, которые возникают в романе, при всем психологическом их разнообразии, как правило, имеет единую и совершенно определенную первопричину. Это покушение цивилизации («головного», отвлеченного, оформленного, сознательного начала в мироздании) против естественного бытия. Собственно, название «Война и мир», которое часто и на разные лады интерпретировалось всеми, кто размышлял о толстовском шедевре, прежде всего означает именно такое противостояние (или же в какие-то периоды простое сосуществование) естественной жизни и цивилизации - согласно представлениям Толстого, жизни и не-жизни. Действующие лица романа и до некоторой степени целые народы проходят в «Войне и мире» через бесконечные «ловушки» цивилизации, чтобы самим ходом событий, в дальнейшей жизни и даже в смерти приблизиться к торжеству толстовской эмоциональной правды и «данного нам в ощущениях» («прелести» бытия, как любит говорить писатель) безличного сверхчувственного начала вселенной.

Богучаровский «бунт», очевидно спровоцированный наполеоновскими соблазнами, при всей укорененности эпизода в действительных происшествиях национальной истории оказался в этом смысле одним из показанных в романе, хотя и крайне своеобразным, цивилизованным «вывихом» естественной жизни. Нечто подобное происходило у Толстого и в судьбах отдельных героев (скажем, наполеоновская мечта князя Андрея Болконского, несостоявшаяся измена своему жениху - Болконскому - 
Наташи Ростовой, масонские искания Пьера Безухова) и в событиях большого исторического масштаба (обернувшееся катастрофой насквозь политическое, «головное», как полагал Толстой, сражение под Аустерлицем). Больше того, сказанное относится не только к «Войне и миру», но и к другим произведениям писателя (самый показательный пример - почти вся от начала до конца повесть «Отрочество» и то место, которое занимает она в толстовской трилогии о становлении человека).

Такого рода цивилизованные покушения на человека и мир почти всегда выглядят у Толстого как более или менее глубокие помрачения душевной жизни отдельной личности или психологии масс, описанные, как правило, с необычайной, потрясающей воображение рельефностью. Нередко в них можно было бы увидеть признаки настоящего постороннего вторжения или даже беснования (безобразное поведение подростка Иртеньева в «Отрочестве», нравственное «падение» Наташи во II томе «Войны и мира»), если бы они не занимали своего места в единой художественной концепции произведения, предлагающей все-таки иные этические категории. Вместе с тем именно философское «выпадение» художника из русской духовной традиции становится в каждом из этих случаев источником столь же чрезвычайного психологического реализма.

Нечто подобное происходит и в картинах богучаровского «бунта». Здесь можно увидеть вполне объективную духовную правду истории: смущение крестьян лживыми французскими посулами, пробуждение темных суеверных глубин народного сознания. Тень Пугачевщины действительно присутствует в этом не вполне характерном эпизоде «Войны и мира». Тем не менее отраженный в поэтике романа его философский контекст постоянно проецирует правду русской истории на субъективно авторское понимание происходящего и во многом определяет прямо толстовские способы разрешения действительных противоречий. При этом отношения мужиков и княжны Марьи, почти затаенный характер крестьянского неповиновения (говорят одно, а делают или только подразумевают другое; явного насилия не проявляют, но отъезду княжны из имения всетаки препятствуют) в силу исключительной сосредоточенности писателя на «божественных» с его точки зрения эмоционально-психологических аспектах жизни сообщают эпизоду изумительное правдоподобие. Хоть «божественное» и отравлено здесь (с поправкой на загадочную умствен- 
ную жизнь богучаровских крестьян) рассудочными цивилизованными отвлеченностями.

Давно замечено, что «лекарством от цивилизации» для толстовских героев обычно становится простое и сильное, часто прямо физическое потрясение. Один из наиболее показательных примеров в этом отношении - сцена ранения князя Андрея Болконского под Аустерлицем: «Как бы со всего размаха крепкою палкой кто-то из ближайших солдат, как ему показалось, ударил его в голову» [9, т. 9, с. 544-545]. И Болконский, хотя и опасно раненный, очнулся: обнаружил в себе «человека чувствительного», избавился от наполеоновского недуга. Все вернулось на круги своя. Но, пожалуй, на первом месте по «чистоте приема» у Толстого должна находиться сцена из повести «Отрочество», которая избавляет от пережитого помрачения Николеньку Иртеньева, кругом виноватого перед своими близкими. Вместо цивилизованного, обдуманного наказания розгами, которое обещал ему ненавистный гувернер St-Jérôme, собственный отец Николеньки просто взял и в порыве гнева «нецивилизованно» выдрал подростка за ухо. «Несмотря на то, что я ощущал сильнейшую боль в ухе, - говорилось в повести, - я не плакал, а испытывал приятное моральное чувство» [9, т. 2, c. 49]. Разразившиеся затем рыдания уже окончательно поправили дело. «Исцеленный» подросток заснул и через двенадцать часов, как было сказано в повести, чувствовал себя совершенно здоровым. Усмирение напомнившей было о себе Пугачевщины состоялось в «Войне и мире» так же осязаемо и так же по-отечески.

Все нравственное, что переживали и делали герои романа, обычно совершалось необдуманно и непреднамеренно. При этом, отражаясь на эмоциональном состоянии других героев, любые поступки, движения или только брошенные взгляды, не отравленные рассуждением и расчетом, безошибочно укрепляли взаимное согласие, вели к восстановлению утраченной гармонии мира и человеческих отношений. Николай Ростов совершенно случайно оказался в «мятежном» Богучарове. И был глубоко тронут обстоятельствами, в которых застал княжну Марью: «"Беззащитная, убитая горем девушка, одна, оставленная на произвол грубых, бунтующих мужиков! И какая-то странная судьба натолкнула меня сюда!" думал Ростов, слушая ее и глядя на нее. - "И какая кротость, благородство в ее чертах и в выражении!” думал он, слушая ее робкий рассказ» [9, т. II, с. I6о]. Этим 
рассказом, точнее, чувством, которое моментально сообщилось герою, был определен весь дальнейший ход событий: «Когда она заговорила о том, что всё это случилось на другой день после похорон отца, ее голос задрожал. Она отвернулась и потом, как бы боясь, чтобы Ростов не принял ее слова за желание разжалобить его, вопросительно-испуганно взглянула на него. У Ростова слезы стояли в глазах. Княжна Марья заметила это и благодарно посмотрела на Ростова тем своим лучистым взглядом, который заставлял забывать некрасивость ее лица» [9, т. ІІ, с. І6о-г6г].

Дальнейшие события в романе могут служить почти эталонным примером толстовской поэтики непреднамеренного действия как высшего проявления единственно значимой в романе эмоциональной нравственности. Ростов поступил необдуманно, повинуясь только душевному порыву, и, как выяснилось, очень результативно: «- Я им дам воинскую команду... Я их попротивоборствую, - бессмысленно (здесь и далее в цитате выделено мной. - А.Г.) приговаривал Николай, задыхаясь от неразумной животной злобы и потребности излить эту злобу. Не соображая того, что будет делать, бессознательно, быстрым, решительным шагом он подвигался к толпе. И чем ближе он подвигался к ней, тем больше чувствовал Алпатыч, что неблагоразумный поступок его может произвести хорошие результаты. То же чувствовали и мужики толпы, глядя на его быструю и твердую походку и решительное, нахмуренное лицо. <...> “Шапки долой, изменники!” - крикнул полнокровный голос Ростова...» [9, т. ІІ, с. I62-I63].

Все, что случилось потом, хорошо известно. Поразивший богучаровских мужиков массовый «вывих сознания» Николай Ростов решительно «вправил» всего лишь одной молодецкой зуботычиной, полученной зачинщиком беспорядков Карпом. Возможно даже, крестьяне, подобно отроку Иртеньеву из давней повести, испытали от всего происходящего «приятное моральное чувство». Во всяком случае они, словно очнувшись от сна, дружно стали вязать тут же снятыми с себя кушаками неблагонадежного Карпа, а заодно и старосту Дрона. Естественно, мирно и дружелюбно крестьяне собрали княжну Марью в дорогу, а не помнившая зла княжна Марья простила своим крепостным все обиды. Психофизическое потрясение не в первый и не в последний раз на страницах романа возвратило естественную жизнь к ее неомраченному (даже посреди войны) нравственному течению. А Николай Ростов неожиданным для себя усмирением смуты к тому же 
приобрел личное счастье - спаситель и заступник, он нашел свою будущую жену: «Все хорошо, что хорошо кончается».

Казалось бы, богучаровское «недоразумение» разрешилось в романе почти трогательным «единением» (любимое слово Толстого) господ и крепостных. Однако простодушие и покорность усмиренных мужиков в заключительной части эпизода, конечно, принесли только временное (хотя и необходимое) умиротворение. Откровенно комический характер «сцены усмирения» едва ли может вызывать иллюзии на этот счет. Помнится, пушкинский Петруша Гринев называл увиденную в Белогорской крепости присягу самозванцу «ужасной комедией». И тому же Гриневу в захваченной Пугачевым крепости накидывали петлю на шею тоже сердечные, простодушные люди: «“Не бось, не бось”,- повторяли мне губители, может быть и вправду желая меня ободрить» [8, с. 308]. Грань между народным добродушием и народным зверством, «остервенением» часто в истории оказывалась почти неуловимой. Такого прочтения богучаровский эпизод романа, хотя и подчиненный единой философии «Войны и мира», тоже никак не исключал.

Авторская позиция Толстого в «мятежном» богучаровском эпизоде, подобно тому, как это происходит во всем огромном романе, ясно отражала авторскую философскую концепцию - во многом утопическую. Но именно это обстоятельство одновременно с парадоксами вызвало к жизни художественный реализм высшей пробы, определило собой колоссальный масштаб толстовского замысла, принесло огромные психологические открытия.

\section{Список литературы}

I Беседа столетнего подмосковного жителя с пленным французским солдатом. СПб.: В тип. Военного министерства, г8гз. І6 с.

2 Бестужев-Рюмин А.Д. Краткое описание происшествиям в столице Москве в г8г2 году // Чтения в Обществе истории и древностей российских. г859. № 2. С. I-6I9.

3 Волконский Д.М. Дневник // І8І2 год... Военные дневники. М.: Русская книга, I990. С. I-464.

4 Грибоедовская Москва в письмах М.А. Волковой к В.И. Ланской // Вестник Европы. І874. № 8. С. 572-666.

5 Гулин А.В. На Поклонной горе (Москва и Наполеон в романе Л.Н. Толстого «Война и мир») // Литература в школе. 2002. № 9. С. 7-І2.

6 Кононов А.А. Воспоминания о І8І2 и г8г3 годах // Чтения в Обществе истории и древностей российских. І86о. Кн. 3. С. I-624. 
7 Липранди И.П. Еще о фальшивых ассигнациях І8І2 г. // Русский архив. І865. C. $873-882$.

8 Пушкин А.С. Полн. собр. соч.: в го т. Л.: Наука, І978. Т. 6.575 с.

9 Толстой Л.Н. Полн. собр. соч.: в 90 т. М.: Худож. лит., І928-І958.

Iо Трифильев Е.П. Очерки из истории крепостного права в России: Царствование императора Павла Первого. Харьков: Тип. «Печатное дело», І904. 360 с.

II Шишков А.С. О пребывании французов в Москве. СПб.: В тип. Императорского театра, І8І2. I6 c.

\section{References}

I Beseda stoletnego podmoskovnogo zhitelia s plennym frantsuzskim soldatom [The Conversation of a Ioo-Year-Old Moscow Region Resident with a Captive French Soldier]. St. Petersburg, Voennogo ministerstva Publ., I8I3. I6 p. (In Russ.) Bestuzhev-Riumin A.D. Kratkoe opisanie proisshestviiam v stolitse Moskve v I8I2 godu [Brief Description of the Incidents in Moscow in I8I2]. Chteniia v Obshchestve istorii i drevnostei rossiiskikh [Readings of the Society of Russian history and antiquities], I859, no 2, pp. I-6I9. (In Russ.)

3 Volkonskii D.M. Dnevnik [Diary]. I8I2... Military diaries [I8I2 ... War diaries]. Moscow, Russkaya kniga Publ., I990, pp. I-464. (In Russ.)

4 Griboedovskaia Moskva v pis'makh M.A. Volkovoi k V.I. Lanskoi [The Griboyedov Moscow in M.A. Volkova's Letters to V.I. Lanskaya]. Vestnik Evropy, I874, no 8, pp. 572-666. (In Russ.)

5 Gulin A.V. Na Poklonnoi gore (Moskva i Napoleon v romane L.N. Tolstogo "Voina i mir") [On Poklonnaya Hill (Moscow and Napoleon in L.N. Tolstoy Novel "War and Peace")]. Literatura v shkole, 2002, no 9, pp. 7-I2. (In Russ.)

6 Kononov A.A. Vospominaniia o I8I2 i I8I3 godakh [Memories of the Years I8I2 and I8I3]. Chteniia $v$ Obshchestve istorii i drevnostei rossiiskikh [Readings of the Society of Russian History and Antiquities], I860, no 3, pp. I-624. (In Russ.) Liprandi I.P. Eshche o fal'shivykh assignatsiiakh I8I2 g. [More on Counterfeit Banknotes of I8I2]. Russian archive [Russkii Arkhiv], I865, pp. 873-882. (In Russ.)

8 Pushkin A.S. Polnoe sobranie sochinenii: $v$ Io $t$. [Complete Works: in Io vols.] Leningrad, Nauka Publ., I978. Vol. 6. 575 p. (In Russ.)

9 Tolstoi L.N. Polnoe sobranie sochinenii: $v 90$ t. [Complete Works: in 90 vols.]. Moscow, Khudozhestvennaia literatura Publ., I928-I958. (In Russ.) Trifil'ev E.P. Ocherki iz istorii krepostnogo prava v Rossii: Tsarstvovanie imperatora Pavla Pervogo [Essays on the History of Serfdom in Russia: the Reign of the Emperor Paul the First]. Kharkov, Pechatnoe delo Publ., I904.360 p. (In Russ.)

II Shishkov A.S. O prebyvanii frantsuzov v Moskve [On the Stay of the French Soldiers in Moscow]. St. Petersburg, Imperatorskogo teatra Publ., I8I2. I6 p. (In Russ.) 